\title{
MARITIME PORT PRICING AND GOVERNANCE IN SOUTH AFRICA: TRENDS AND STAKEHOLDER COMMENTS
}

\author{
Sanele Gumede* \\ University of KwaZulu-Natal \\ gumedes@ukzn.ac.za
}

Received: December 2013

\author{
Mihalis Chasomeris" \\ University of KwaZulu-Natal \\ chasomerisml@ukzn.ac.za
}

Accepted: May 2014

\begin{abstract}
This study assesses trends and stakeholder comments on maritime port pricing and governance in South Africa. Content analysis is used to analyse Transnet National Ports Authority (TNPA) tariff applications, Ports Regulator records of decision and stakeholder comments for 2010 to 2012. The study gathers data on port pricing from 1999-2012 and uses descriptive statistics to analyse the trends in port pricing. The findings show the distinctiveness of South Africa's complementary system of ports and its uniform pricing policy. The ports are financed and managed using a mix of elements from the European and Asian port doctrines, whereas the pricing methodology appears to follow the Anglo-Saxon doctrine. A port doctrine should be developed that would be consistent with the country's vision and policies.
\end{abstract}

Keywords

Port pricing, South Africa, Port Doctrine, Transnet National Ports Authority

*Mr S Gumede is a developmental lecturer, School of Accounting, Economics and Finance, University of KwaZulu-Natal, South Africa.

\#Dr M Chasomeris is a senior lecturer at the Graduate School of Business and Leadership, University of KwaZulu-Natal, South Africa. 


\section{INTRODUCTION}

The South African government has recognised the importance of promoting efficient and effective transport, including the strategic role of maritime ports in the logistics chain (NFLS, 2005; Havenga, 2010; Chasomeris, 2011a). Several studies (Jones, 1988; Department of Transport, 2002; NFLS, 2005; Chasomeris, 2011b) show that South Africa's maritime stakeholders have justifiably been dissatisfied with port governance, policy and pricing that has promoted: import substitution; intra- and inter-port cross-subsidisation; inter-modal cross-subsidisation; insufficient investment in port infrastructure and superstructure; bureaucracy and skewed pricing. Additionally, the South African port structures have displayed monopoly power, which prevents competition and promotes a complementary system of ports which has a unitary pricing system, that is, a single tariff book that applies to all eight commercial ports (Gumede and Chasomeris, 2012).

This study critically assesses stakeholder comments on maritime port pricing in South Africa. More specifically, the study uses content analysis to analyse three Transnet National Ports Authority (TNPA) tariff applications, three Ports Regulator records of decision and 48 stakeholder comments for the tariff years 2010-12. The study gathers data on port pricing from 1999-2012 and uses descriptive statistics to analyse the trends in port pricing. South Africa's port context is compared and contrasted with the three port pricing paradigms identified in the literature, namely, the Anglo-Saxon, the European and the Asian port doctrines.

This study proceeds as follows. Section 2 presents the research methodology. Section 3 discusses the literature reviewed on port models, port doctrines and pricing paradigms, and shows that South Africa's port model and pricing are distinct. Section 4 discusses South Africa's port doctrine in comparison with the three port doctrines identified in the literature. Section 5 discusses the context of South Africa's port charges and challenges. Section 6 shows the findings of the content analysis on the stakeholder comments on port pricing. Section 7 provides conclusions and recommendations.

\section{RESEARCH METHODOLOGY}

Each year TNPA is required to apply to the Ports Regulator of South Africa for the approval of port tariffs. The Ports Regulator invites port stakeholders to submit comments on port pricing and TNPA's application. For three tariff years, stakeholders have expressed their perspectives. This study uses the population of comments recorded over these three years, which includes: the TNPA tariff applications, the publically available stakeholder comments on the TNPA application, the Ports Regulator records of decision and TNPA's response to the records of decision. These views require further assessment to find the best way forward for South Africa's port governance and pricing.

This study uses content analysis to critically assess contemporary stakeholder comments on maritime port pricing in South Africa. Content analysis is "a systematic research method for analysing textual information in a standardized way that allows evaluators to make inferences about that information" (Crowley and Delfico, 1996:6). Content analysis is used to analyse three Transnet National Ports Authority (TNPA) tariff applications, three Ports Regulator records of decision and 48 stakeholder comments for 2010-12. The 48 stakeholder comments were submitted as follows: three stakeholders submitted non-confidential comments in tariff year 
2010/11, 30 stakeholders in 2011/12 and 15 stakeholders in 2012/13. The comment documents varied in length, with one page being the shortest submission and 163 pages being the longest. The study extracts the stakeholders' main concerns, codes them into different themes and analyses their frequency distribution. In addition, the study gathers data on South Africa's port pricing and inflation from 1999-2012 and uses descriptive statistics to analyse trends. South Africa's port context is compared and contrasted with the three port pricing paradigms identified in the literature, namely, the Anglo-Saxon, the European and the Asian port doctrines.

\section{SOUTH AFRICA'S PORT MODEL}

South Africa's port model is distinct. South Africa's eight commercial ports are state-owned. The state-owned enterprise (SOE), Transnet, is both the port landlord, in the form of Transnet National Port Authority (TNPA), and the port operator, in the form of Transnet Port Terminals (TPT). Even though both the Ports Regulator of South Africa and Transnet are state-owned, they are independent of each other. TABLE 1 shows a Port Function Matrix. The matrix offers a conceptual framework to better understand four port models of regulation, ownership and operation. In a study of the world's top 100 ports, Mouknass (2001) categorises seven ports under model 1; 88 ports under model 2; two ports under model 3; and the remaining three ports under model 4.

TABLE 1: Port Function Matrix

\begin{tabular}{lcccc}
\multicolumn{1}{c}{ Port models } & Port Functions & & The world's Top \\
& Regulator & Land Owner & Operator & 100 ports \\
\hline 1. Public & Public & Public & Public & 7 \\
2. Semi-Public & Public & Public & Private & 88 \\
3. Semi-Private & Public & Private & Private & 2 \\
4. Private & Private & Private & Private & 3 \\
South African & Public & Public & Public \& Private & - \\
\hline
\end{tabular}

Source: Adapted from Baird (1997 cited in Song and Lee, 2007); Mouknass (2001) and Chasomeris (2011b)

Mouknass (2001) categorised South African ports under the first model, which is the public port model. In contrast, this study and Gumede and Chasomeris (2012) examine the distinctness of the South African port model and note that it consists of both private and public operators (see TABLE 2). Furthermore, TABLE 2 shows the distribution between public and private market share for port operations. The cargo handling of high-value cargoes, like containers and motor vehicles, are largely provided by the public sector, whereas the private sector has a larger market share in the handling of lower-value bulk cargoes. This institutional structure has caused discontent, especially among the private sector, as private terminals compete with public terminals for market share, under the scrutiny of the public Ports Regulator. Unlike the four typical port models shown in TABLE 1 , South Africa has both public and private sector operators. TABLE 2 shows the market share and distribution between the public and private sector operators. 
TABLE 2: Public and Private Sector Market Share for Major Service Categories

\begin{tabular}{lccc}
\hline \multicolumn{1}{c}{ Service } & TNPA & Port Operation \\
& & SOE - TPT & Private Sector \\
\hline Marine services & $100 \%$ & \\
Bulk cargo handling & $37 \%$ & $63 \%$ \\
\hline Break-bulk cargo handling & $78 \%$ & $22 \%$ \\
Container handling & $97 \%^{a}$ & $3 \%^{b}$ \\
\hline Car (on wheels) handling & $100 \%$ & \\
\hline
\end{tabular}

Source: Ports Regulator, 2010a:31

a. These figures are approximations based on testing actuals on a limited number of cargo terminal owners.

b. This figure is derived by excluding the containers that move through the multipurpose terminals, as the majority are TPT-run; thus analysis of private terminal operators indicates that private terminals handle only $3 \%$ of national container traffic.

High port performance and public ownership are not mutually exclusive; and there is no simple relationship between port performance and adherence to standard landlord or operating port structures (Mouknass, 2001; Ports Regulator, 2010a; Chasomeris, 2011b). The Ports Regulator (2010a:32) states that "the explanation for high port performance is mostly to be found in forms of market structure and competition within those markets for port services and operations". Transnet (2010) believes that the current institutional structure has not resulted in an inefficient freight system. Transnet (2010) argues that the South African freight system has several challenges, such as skills shortages, increased congestion, poor regional integration, weak maritime connectivity and the carbon intensity of the current system. Hence, as the custodian of ports, rail and pipelines, the focus of Transnet is on overcoming these challenges. Furthermore, "Transnet's strategy is focused on expanding the utility, connectivity and capacity of its integrated infrastructure network which is its core competitive advantage and source of asset value" (Transnet, 2010:5). In addition, Transnet (2010) states that the current institutional structure makes it possible for Transnet to tackle these challenges.

The Ports Regulator (2010a) review suggests that the efficiency and effectiveness of the ports should be pursued by increasing inter- and intra-port competition. Botes (2006:30-4) argues that "competition between ports is the only way to bring prices down in the long term through exploitation of their competitive advantage ... Policies and legislation should encourage more effective competition between ports to eliminate pricing anomalies and to offer a better choice of service". Likewise, Thompson (2009:17) states: "without competition, the ports offer an irresistible opportunity to generate monopoly rents that are then transferred to employees or the owning agency, or others, usually with highly opaque accounting. Consolidated accounting erases the ability to measure the results of any individual port."

Thompson (2009) argues that the powers of Transnet prevent competition; however, Notteboom (2011:52) states that "it creates an excellent environment for coordination among ports and between the ports and the rail system". Indeed, South Africa is working towards implementing a democratic developmental state where "strategic control of the core infrastructure network remains within the state, which allows for coordinated long-term network planning and makes the state more resilient to economic shocks" (Transnet 2010: 5). Transnet believes that the current institutional structure is consistent with the concept of a democratic developmental 
state and that it will remain the dominant owner and operator of certain parts of the freight system for many years to come (Transnet 2010:5-24). Gumede and Chasomeris (2012:92) note that "since the country's focus on a democratic developmental state, the port reform rhetoric in South Africa has clearly shifted from discussions on the potential concession of port terminals to discussions on public-private partnerships".

\section{SOUTH AFRICA'S PORT DOCTRINE: A CLASH OF PARADIGMS}

A port's pricing strategy is dependent on the way it is financed and on the ownership status of the port. Gumede and Chasomeris (2012) argue that it is paramount to consider the vision, and economic and political context that the maritime port is operating under, before applying a particular port strategy. Bennathan and Walters (1979) theorised that although ports may be operating under different conditions, they were operating either under the European (Continental) doctrine or under the Anglo-Saxon doctrine. The European doctrine "views the port as part of the social infrastructure and hence assesses its value in terms of contribution to the development of the region and not necessarily in terms of profitability" (Strandenes and Marlow, 2000:4). Ports under the European (Continental) doctrine pursue the direction of the development of the national and/or the regional economy and such ports are usually constructed under the auspices of public funds (Lee \& Flynn, 2011). Lee and Flynn (2011) note the typical expected benefits for the Continental doctrine, which include cheaper transportation costs, job creation in the course of port construction and also multiplier impacts for social welfare. In contrast, the Anglo-Saxon doctrine does not pursue objectives of the regional and/or the national interests. Lee and Flynn (2011:793) argue that the Anglo-Saxon doctrine "requires port developers to evaluate port development on the basis of commercial cost accounting so that port charges should be borne by port users to meet investment hurdle rates required by investors." Under the Anglo-Saxon doctrine, ports are operated under pure business principles, and thus, in practice, port prices will be expected to be higher than those under the European doctrine. Lee and Flynn (2011:793) argue that "such higher port charges of the Anglo-Saxon approach would in theory lead to lesser port competitiveness compared with ports under the European Doctrine." Investors in the Anglo-Saxon doctrine usually require higher rates of returns on their deployed capital, normally under a short period of time, and hence implementation of large port developments may be hindered (Lee \& Flynn, 2011). Cross-subsidisation is more likely to occur under the European than under the Anglo-Saxon doctrine, especially regarding the expansion of ports and the development of new ports.

Lee and Flynn (2011), identify eleven elements of a proposed Asian doctrine which are not featured in the Anglo-Saxon or the European doctrines. In most Asian ports, central government has been the sole role player in port investment, port design, port development, port operations, price-making, and port mediation (Lee \& Flynn, 2011). Lee and Flynn (2011) note that the function of prominent Asian ports is closely interconnected to the national economic development plans. Furthermore, "the Asian Doctrine contends that port assets and related infrastructure should be in the public sector to avoid the risk of monopolisation by private firms, and sea ports should be regarded as fundamental assets of and national security for the national economy" (Lee \& Flynn, 2011:796).

South Africa's ports cannot be clearly categorised under the European, Anglo-Saxon or Asian doctrines. South Africa practices elements of these contesting paradigms concurrently. South African ports are nationally owned and governed, having a vision to promote public interests, 
and at the same time, to exploit its comparative advantage in the pursuit of its objectives. On the one hand, port investments aim to facilitate economic growth and trade, and create capacity ahead of demand. Section 2 (a) of the NPA Act (2005:11) highlights the first objective of the act, which is "to promote the development of an effective and productive South African ports industry that is capable of contributing to the economic growth and development of our country." On the other hand, South Africa's ports are required to be self-sufficient. Pricing decisions aim to ensure that ports are able to recover their costs and investments and are able to be profitable. TNPA (2009:8) submitted that tariffs should cover all "costs and make a return on the fair value of assets commensurate with the opportunity cost of capital and which provide for necessary investment in port infrastructure and related assets." Clearly this is a direct transfer of costs from TNPA to port users. This method ultimately means that port users would pay for (1) all ports investments, (2) all ports costs, and (3) for TNPA to make a profit. This method guarantees TNPA a profit regardless of whether TNPA is efficient or productive.

\section{SOUTH AFRICA'S PORTS: CHARGES AND CHALLENGES}

South Africa's port system has a number of challenges, including: issues relating to infrastructure, port under-investment, out of date technology, old machinery, availability of port space, inconsistent and high pricing of facilities, poor scheduling of facilities, increasing congestion, skills shortages, availability of dedicated personnel to liaise with and make timeous decisions in relation to the industry, availability and functionality of equipment, the country's high level of unemployment, poor regional integration, the carbon intensity of the current system, weak maritime connectivity and identification, and resolution of problems as they arise (Department of Trade and Industry, 2010; Transnet, 2010; Ports Regulator, 2009; 2010b; 2011).

The legacy of South Africa's freight system and port pricing strategy reflects a system designed to support an import substitution economy. Before 2002, South African ports set prices well below full cost recovery for a number of port functions, including marine infrastructure and services. Port dues generated revenues below associated costs. Cargo handling charges were closer to related costs, but fell short of full cost coverage. Cargo functions were thus being used to subsidise marine functions (Jones 1988; Chasomeris, 2011a).

To achieve a more fair, efficient and competitive system, it was essential that ad valorem wharfage be eliminated. In May 2002, wharfage charges were replaced with a set of cargo dues that are cost-related and reduce the previous discrimination against high-value cargo, bringing South Africa more in line with international practices (Jones, 2002). Cargo dues are levied on a unit basis (set box rate) for containers and a tonnage (volume) basis for other forms of cargo. The transformation of wharfage into cargo dues attempted to reduce the extent of crosssubsidisation and cost-price irregularities across marine and cargo functions (Jones, 2002). The increase in marine charges helps to lessen the effects of intra-port cross-subsidisation. Additionally, the TNPA expressed its intent to keep adjustments in port costs aligned with the country's inflation targets (Chasomeris, $201 \mathrm{la}$ ). Indeed, from 2005 until 2009 TNPA maintained below inflation port price increases. TABLE 3 shows the percentage change in the country's consumer price index (CPI), marine services, port and berth dues, as well as cargo dues from 1999 to 2012.

Since 2009, TNPA has been required to apply annually for tariff adjustments to the Ports Regulator. The Ports Regulator then calls for stakeholder comments on TNPA's proposed port tariff application. 


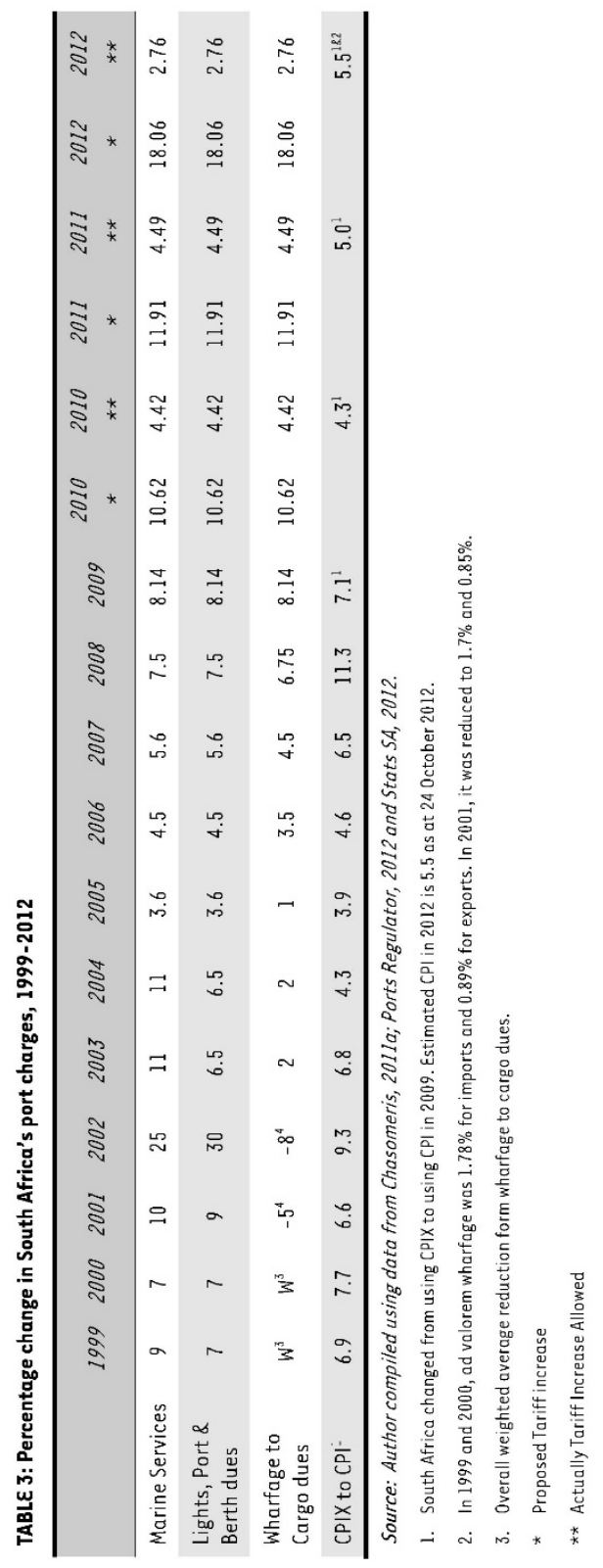


The Ports Regulator then assesses TNPA's proposal and the stakeholder submissions in line with the National Ports Act 12 of 2005, National Commercial Port Policy of 2002 and the draft directives of 2008 to make a decision on the port tariff application. TNPA uses the required revenue method to motivate for its tariff increases. This methodology does not give incentives for TNPA to reduce costs; it guarantees TNPA profits regardless of costs, including those costs which may have been caused due to inefficiencies.

In 2010, the Ports Regulator approved a tariff increase of $4.42 \%$, which was slightly above the country's inflation rate. For 2011, TNPA applied for an $11.91 \%$ tariff increase. The Ports Regulator approved a tariff increase of $4.49 \%$, which was slightly below the country's inflation rate of $5 \%$. For 2012 , TNPA applied for a tariff increase of $18.06 \%$ which was more than three times the country's inflation rate. The Ports Regulator allowed a tariff increase of $2.76 \%$.

Although the difference between the applied tariff increase and the allowed tariff increase is significant, the annual revenues accruing to TNPA appear to be consistently higher than their initial revenue required. FIGURE l shows results for tariff years 2010 to 2012.

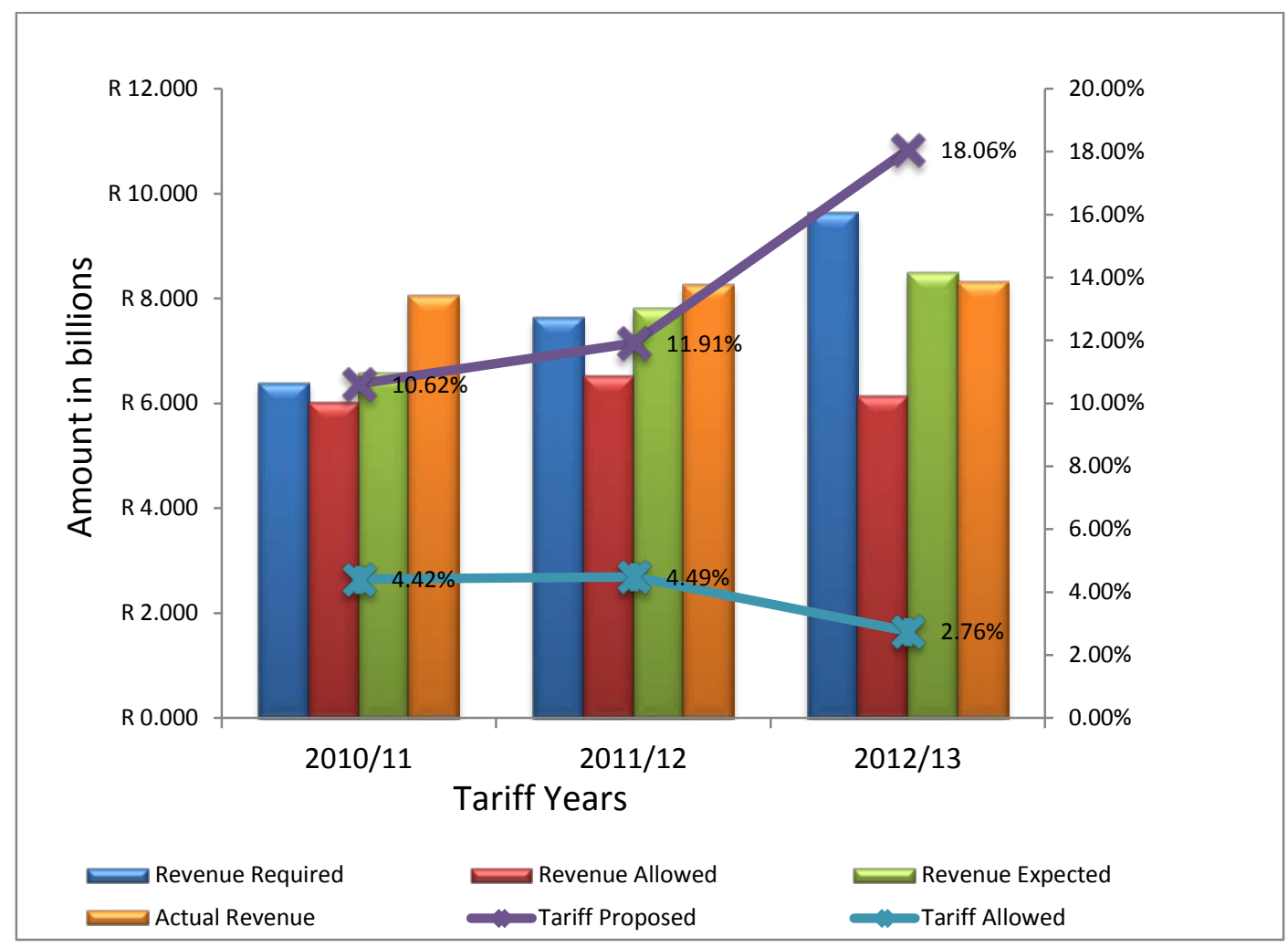

FIGURE 1: Tariff results for 2010/11, 2011/12, and 2012/13 Tariff years

Source: $\quad$ Authors compiled using data from TNPA (2009; 2010; 2011 and 2012) and Ports Regulator (2010b; 2011; and 2012)

TNPA applied for revenue of R6,377 billion for 2010; R7,641 billion for 2011; and R9,645 billion for 2012. In order to achieve such revenue, TNPA applied for tariff increases of $10.62 \%, 11.91 \%$ and $18.06 \%$ respectively. However, the Ports Regulator allowed lower revenue of R6,02 billion for 
2010; R6,523 billion for 2011; and R6,15 billion for 2012. Consequently, lower tariff increases of $4.42 \%, 4.49 \%$, and $2.76 \%$, respectively, were approved. Nonetheless, with the approved tariff increases, TNPA submitted that they expected to recover revenue of R6,584 billion for 2010 and $\mathrm{R} 7,807$ billion for 2011 . These expected revenues are a clear indication of over-recovery, as they are above both the Ports Regulator's allowed revenue and the initial revenue required by TNPA.

\section{ANALYSES OF STAKEHOLDER COMMENTS FOR 2010 TO 2012}

TABLE 4 contains a summary of the themes that emerged from the content analysis of the stakeholder submissions to the Ports Regulator for tariff years 2010 to 2012. The table shows that, over the three years, 30 stakeholder comments stated that South Africa's port tariffs are among the highest in the world. This concurs with a benchmark study by Maersk (2011) for the vessel Safmarine Nokwanda. The vessel called at three South African ports and 12 foreign ports, and revealed an average port cost of US\$18 990 per port call, while South Africa's port charges were higher and ranged from US\$35 474 to US\$40 556 per port call. Moreover, only South Africa charged cargo dues for containers. However, in terms of productivity, all South African ports are featured in the study in the bottom six, as they could only achieve a range from 22 to 35 berth moves per hour, while the average for the 15 ports was 55 . Maersk used berth moves per hour to measure productivity. Although this was not explained, presumably it refers to container moves, either in TEUs (twenty-foot equivalent units, that is, a six-metre container) or actual number of containers (though these may be very different measures, as they could include six-and twelvemetre containers). The standard methods to measure terminal or port productivity, in the container trade, are either in container moves per gantry crane $(\mathrm{GCH})$, or in container moves per ship working hour (SWH).

TABLE 4: Stakeholder Comments on Port Pricing in South Africa, 2010 to 2012 tariff years

\begin{tabular}{|c|c|c|c|c|}
\hline \multirow[b]{2}{*}{ Stakeholder Comments } & \multicolumn{4}{|c|}{ Number of comments submitted } \\
\hline & $\begin{array}{c}2010 \\
3\end{array}$ & $\begin{array}{c}2011 \\
30\end{array}$ & $\begin{array}{c}2012 \\
15\end{array}$ & $\begin{array}{c}\text { TOTAL } \\
48\end{array}$ \\
\hline Global competitiveness & 2 & 15 & 13 & 30 \\
\hline $\begin{array}{l}\text { Port tariffs in South Africa are among the highest in the } \\
\text { world. High port tariffs hinder the country's and } \\
\text { exporters' global competitiveness }\end{array}$ & $66.67 \%$ & $50.00 \%$ & $86.67 \%$ & $62.50 \%$ \\
\hline Economy & 3 & 13 & 8 & 24 \\
\hline $\begin{array}{l}\text { High port tariffs hinder SA's economic growth. They } \\
\text { increase costs of doing business in the country }\end{array}$ & $100.00 \%$ & $43.33 \%$ & $53.33 \%$ & $50.00 \%$ \\
\hline Above inflation & 3 & 12 & 7 & 22 \\
\hline $\begin{array}{l}\text { The applied for tariff increase is above the country's } \\
\text { inflation rate (Consumer Price Index) }\end{array}$ & $100.00 \%$ & $40.00 \%$ & $46.67 \%$ & $45.83 \%$ \\
\hline Tariff methodology & - & 9 & 9 & 18 \\
\hline $\begin{array}{l}\text { Tariff methodology does not provide incentive for TNPA to } \\
\text { reduce costs. The required revenue guarantees TNPA cost } \\
\text { and investment recovery and profit even though some of } \\
\text { the cost items may be due to inefficiencies }\end{array}$ & - & $30.00 \%$ & $60.00 \%$ & $37.50 \%$ \\
\hline
\end{tabular}


Price increases above tariff applied for

Even though TNPA mention that they are charging a uniform price increase, on certain commodities the increases range from $80 \%$ to $864.6 \%$

Inconsistency and non-compliance

TNPA is not complying fully with the national port policies and legislation. Tariff rationale is inconsistent with the country's economic visions

\section{Low productivity and inefficiency}

South African ports lack efficiency; with huge delays, port congestions, higher turnaround times, few moves per hour, underutilisation.

Transparency on information
TNPA lacks transparency in their reporting and they
provide insufficient information and justification in their
tariff application
Not cost-based
Ports have adopted a policy to charge their tariffs based
on costs; however several products are not cost-based.

Abuse of monopoly power
TNPA abuses their monopoly power over all South Africa
commercial ports

Profitability

High port tariffs hinder port users' profitability. TNPA remain the cash cow for Transnet, having huge profit margins

\begin{tabular}{|c|c|c|c|c|}
\hline Differentiation in tariffs & - & 5 & 3 & 8 \\
\hline $\begin{array}{l}\text { Tariff adjustment for handling each commodity should be } \\
\text { assessed individually }\end{array}$ & - & $16.67 \%$ & $20.00 \%$ & $16.67 \%$ \\
\hline Lob losses & - & 5 & 3 & 8 \\
\hline $\begin{array}{l}\text { High port tariffs lead to huge job losses, as the } \\
\text { stakeholders will have to retrench in order to decrease } \\
\text { costs }\end{array}$ & - & $16.67 \%$ & $20.00 \%$ & $16.67 \%$ \\
\hline Unresolved matters & - & 4 & 1 & 5 \\
\hline $\begin{array}{l}\text { Before further adjusting tariffs there are unresolved } \\
\text { matters that TNPA has to address with the stakeholders } \\
\text { concerned }\end{array}$ & - & $13.33 \%$ & $6.67 \%$ & $10.42 \%$ \\
\hline Customer service & 1 & 3 & - & 4 \\
\hline TNPA should improve customer service in their ports & $33.33 \%$ & $20.00 \%$ & - & $8.33 \%$ \\
\hline Misalignment & - & 3 & - & 3 \\
\hline $\begin{array}{l}\text { Tariffs of some commodities are misaligned with } \\
\text { international tariff levels }\end{array}$ & - & $10.00 \%$ & - & $6.25 \%$ \\
\hline
\end{tabular}


Security efficiency

Some cargo went missing at the port in 2010 - TNPA

should improve their security

\section{1}

$3.33 \%$

Source: Authors analysed and compiled from the 48 stakeholder submissions to the Ports Regulator for Tariff Years 2010-12 (Ports Regulator, 2013).

The stakeholder comments showed 24 respondents stating that higher port tariffs hinder the country's economic growth. In the current low economic growth environment, TNPA proposals for above-inflation tariff increases are considered, by stakeholders, to be undesirable and unrealistic. Eight respondents noted that TNPA makes very high profits, yet it still applies for high price increases. For the three years, TNPA reached a profit margin of an average of $74 \%$, contributing an average of about $36.4 \%$ to Transnet's earnings before interests, taxation, depreciation, and amortisation (EBITDA).

Fifteen respondents submitted that the TNPA tariff applications explicitly propose uniform (standardised) tariff increases for all commodities of $10.6 \%, 11.9 \%$ and $18 \%$ for 2010 to 2012 tariff years respectively. In the actual tariff book proposal, however, one can clearly identify tariff increases for certain commodities that are significantly higher. TABLE 5 shows the liquid bulk and dry bulk export products that have experienced extraordinarily high tariff increases. For example, note the proposed 2011 tariff increases for molasses and products thereof (864\%), chrome ore $(117 \%)$, vermiculite $(204 \%)$ and woodchips (612\%). Chasomeris (2011b:11) states that, "the proposed tariff increases arguably show the intentions of TNPA." With proper regulation, some of the extraordinary increases shown in TABLE 5 were ultimately corrected by the actual tariffs approved by the Ports Regulator. The 2012 tariff proposal shows an attempt by TNPA to rectify other extraordinary tariff increases that were applied in the 2010 tariff year. For example, magnetite experienced a $300 \%$ price increase in 2010, TNPA applied for a $69 \%$ decrease in tariffs of magnetite in 2012. The Ports Regulator, however, approved a tariff decrease of $73 \%$.

Exporters should appreciate the decline in actual tariffs for some of the other break-bulk commodities which resulted from the tariff realignments. Tariffs for ores and minerals: olivine were to decrease by $76 \%$, scrap steel was to decrease by $64 \%$, asbestos and products thereof was to decrease by $46 \%$, aluminum and fluoride and ferric sulphate were to decrease by $44 \%$, chemicals and products thereof were to decrease by $44 \%$, and Magnesium was to decrease by $16 \%$. TNPA has a mandate that includes lowering the cost of doing business in South Africa; however, TNPA is applying for tariffs that are above inflation and may raise the costs of doing business in and from South Africa. The methodology that is currently in place makes it difficult to better detect the direct cost associated with each product. The required revenue model necessitates that port users pay for all port revenues and costs, which may include costs that are due to inefficiencies. TNPA has adopted a user-pays principle, which suggests that each activity's pricing should be cost-based. A proper costing exercise, audited for each cargo commodity type, could assist in clearly measuring the costs associated with each cargo type. Such an exercise would help TNPA to identify areas where productivity may be improved and costs may be reduced. 


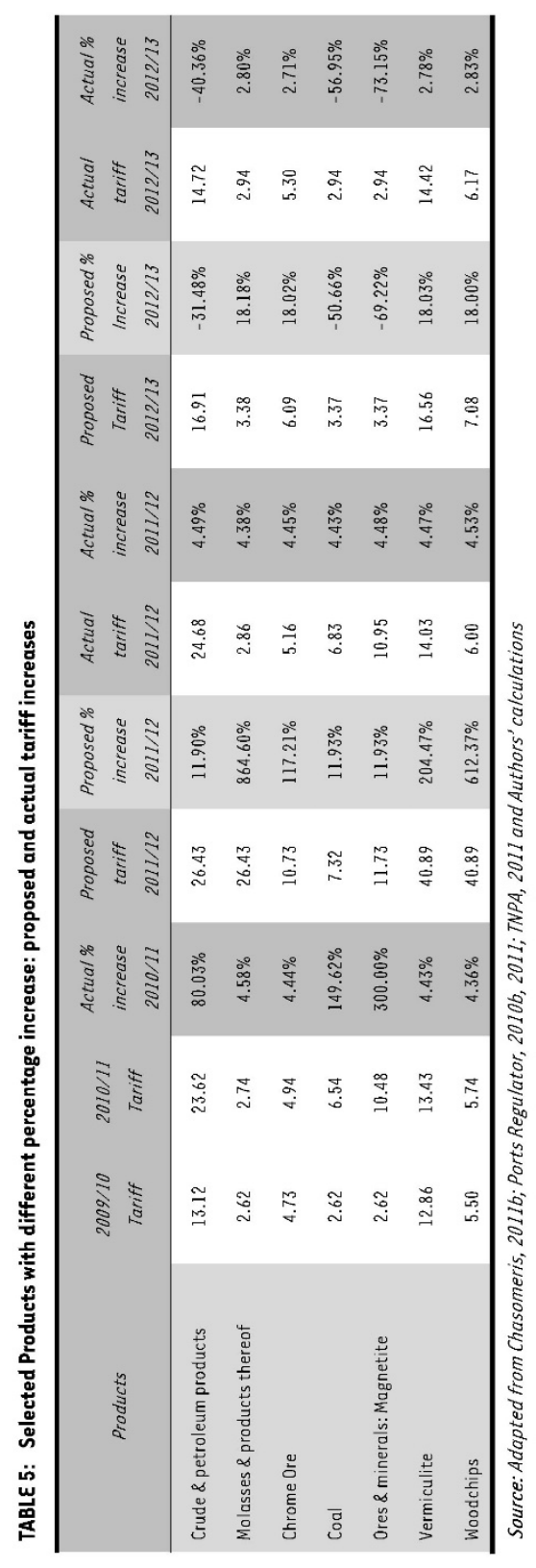


TABLE 6 shows current and proposed structure of required revenue. FIGURE 2 shows the percentage contribution of each port user to the TNPA revenue in the current realised and proposed structures respectively.

TABLE 6: Current and Proposed Structure of Required Revenue

\begin{tabular}{|c|c|c|}
\hline & Current Realised & Proposed Structure \\
\hline Shipping lines & & - Maintenance of wet assets \\
\hline & $\begin{array}{l}\text { - Not based on asset } \\
\text { allocation rationale }\end{array}$ & - Marine Services (e.g. tugs) \\
\hline Cargo owners & $\begin{array}{l}\text { - Current realised revenue } \\
\text { structure mostly result } \\
\text { of historical carry-over } \\
\text { of tariffs }\end{array}$ & $\begin{array}{l}\text { - Provision for all common } \\
\text { infrastructure, typically } \\
\text { government funded elsewhere, e.g. } \\
\text { channels, breakwaters, roads, } \\
\text { bridges }\end{array}$ \\
\hline $\begin{array}{l}\text { Terminal } \\
\text { operators }\end{array}$ & & - Quay Walls \\
\hline
\end{tabular}

Source: Adapted from TNPA, 2012:23

\section{Current Realised}

$\square$ Shipping Lines $\square$ Tenants $\square$ Cargo Owners

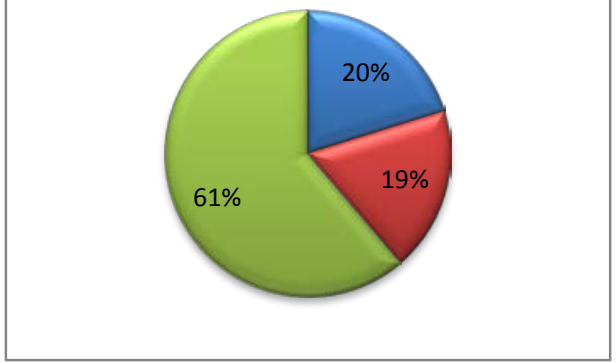

\section{Proposed Structure}

$\square$ Shipping Lines $\square$ Tenants $\square$ Cargo Owners

\section{FIGURE 2: Current Realised and Proposed Structures}

Source: $\quad$ Adapted from TNPA, 2012: 23

Currently, the total rental received by TNPA from tenants is too low (TNPA, 2012). However, the challenge with rental fees is that they are often determined through long-term contracts and cannot be changed regularly. Hence to cover the faster changes in costs, cargo dues are the only variable that can be used in the short run.

The Ports Regulator (2012b: 4) study shows that vessels face much lower overall costs in South Africa than the global averages. These costs are: $26 \%$ below the global norm in the case of containers, $37 \%$ for coal (Richards Bay), $47 \%$ for automotive (Durban); and $57 \%$ for iron ore vessels (Saldana). TNPA (2012a: 20) calculates that based on the provisions allocation of assets to specific port users, shipping lines would be allocated $58 \%$ of total assets. Hence "if the cost 
recovery and user pays principle were applied based on this asset allocation, shipping lines would have to pay more than $50 \%$ of Required Revenue, versus 18\% currently". TNPA (2012a: 22) explains that "not all wet infrastructure should be allocated to shipping lines as this will make the tariffs charged to shipping lines prohibitively expensive compared to other ports internationally" (TNPA, 2012a:20). After various explanations, TNPA ultimately proposed the following contributions to Required Revenue: terminal operators $33 \%$, cargo owners $46 \%$ and shipping lines 21\% (see FIGURE 2).

A greater Required Revenue should be allocated to shipping lines, moving the marine prices closer to the global norm, whilst having no negative consequences for the South African economy. Indeed, higher marine charges may incentivise shipping lines to use larger ships. Larger ships, through economies of scale, should contribute towards lowering the transportation costs of South Africa's international trade. Further consideration needs to be given to the proposed asset allocation to port user groups.

\section{CONCLUSION AND RECOMMENDATIONS}

This study assessed trends and stakeholder comments on port pricing and governance in South Africa. The study used content analysis to analyse three Transnet National Ports Authority (TNPA) tariff applications, three Ports Regulator records of decision and 48 stakeholder comments for 2010 to 2012. The study gathered data on port pricing from 1999 to 2012 and used descriptive statistics to analyse the trends in port pricing.

Port stakeholders criticise TNPA for: abusing its monopoly power; hindering global competitiveness; not taking into cognisance the state of the country's economy; charging prices which are higher than inflation; creating an environment which does not support job creation; being inconsistent and non-compliant with the national policies; not applying cost-based pricing principles; not having a justifiable pricing methodology; low productivity and inefficiency; inconsistent and unreasonable pricing of products; and poor service delivery and port security.

South Africa's ports system is distinct with its complementary system of ports, largely uniform pricing policy, and its public and private sector share of port operations.

Three port pricing paradigms are identified in the literature, namely, the Anglo-Saxon, the European and the Asian port doctrines. The findings show that South Africa has elements of all three contesting port doctrines. In essence, South Africa's ports are financed and managed using a mix of elements from the European and Asian doctrines, but appear to be attempting to charge tariffs according to the Anglo-Saxon doctrine. The clash in port doctrines is a source of misunderstanding and contention.

South Africa needs to develop a port doctrine that would be consistent with the country's visions and policies. There is a need to improve transparency on the port pricing methodology and tariff structure. As TNPA aspires to implement user-pay and cost-based pricing principles, a proper costing exercise, audited for each cargo commodity type, would help to measure the actual costs associated with each cargo type. Such a costing exercise would help TNPA and port stakeholders to identify areas where productivity may be improved, where costs may be reduced and may determine appropriate pricing of various cargoes. Improved access to port data and pricing, as well as transparency in costing methodology, will allow the Ports Regulator and other 
port stakeholders to contribute towards improving the pricing and performance of South Africa's ports.

\section{LIST OF REFERENCES}

Bennathan, \&. \& Walters, A. A. (1979). Port Pricing and Investment Policy for Developing Countries. Published by Oxford University Press for the World Bank.

Botes, F. (2006). Impact of Transport Pricing Practices in South Africa on Freight Transport Costs. HSRC. Pretoria.

Chasomeris, M. (2011a). Port Pricing in South Africa. Proceedings of the European Conference on Shipping Intermodalism \& Ports, $22-24$ June, Chios, Greece.

Chasomeris, M. (2011b). South Africa's Ports: Governance and Pricing Reform. Proceedings of the International Association of Maritime Economists Conference, 26-28 0ctober, Santiago, Chile.

Crowley, B.P. and Delfico, J.F. (1996). Content Analysis: A Methodology for Structuring and Analyzing Written Material. Program Evaluation and Methodology Division. United States General Accounting Office.

Department of Trade and Industry (DTI). (2010). Industry Policy Action Plan (IPAP) 2012/132014/15. [Online] Available: http://www.scribd.com/doc/87684201/Industry-launches-theIndustrial-Policy-Action-Plan-IPAP-2012-13-2014-15 (Accessed 15 September 2012).

Department of Transport. (2002). National Commercial Ports Policy. Government Gazette no. 23715, 8 August 2002.

Gumede, S. \& Chasomeris, M. (2012). Port Governance in South Africa. Interdisciplinary Journal of Economics and Business Law, 1(4), pp. 82-98.

Havenga, J. (2010). Logistics costs in South Africa - the case for macroeconomic measurement. South African Journal of Economics, 78(4), pp. 460-478.

Jones, T. (1988). A General Overview of Harbour Tariff Principles. Proceedings of the S.A. Harbours Conference, 14 April, Sun City, South Africa.

Jones, T. (2002). Invisible Hand effective when Prices in line with True Costs. The Mercury, Highroad for KZN, 5 June.

Lee, T.W.P. \& Flynn, M. (2011). Charting a New Paradigm of Container Hub Port Development Policy: The Asian Doctrine. Transport Reviews: A Transnational Transdisciplinary Journal, 31, pp. 791-806.

Maersk. (2011). Tariff process Submission. Ports Regulator of South Africa. 21 October. [Online] Available: http://www.portsregulator.org/ports_reg_011.htm. (Accessed 23 May 2012).

Mouknass, M. (2001), A Strategy for the Privatization of the Nouakchott Port. [Online] Available: http://www.commercialdiplomacy.org/pdf/ma_projects/moham.pdf (Accessed 20 March 2011).

National Ports Act. (2005). National Ports Act No. 12 of 2005. [Online] Available: http://www.info.gov.za/view/DownloadFileAction?id=67864 (Accessed 15 January 2011).

NFLS. (2005). National Freight Logistics Strategy. Department of Transport. Pretoria.

Notteboom, T. (2011). An application of multi-criteria analysis to the location of a container hub port in South Africa. Maritime Policy \& Management, 38, pp. 51-79. 
Ports Regulator. (2009). Record of Decision: Tariff Application by the National Ports Authority for the Tariff Year 2009/2010.

Ports Regulator. (2010a). Ports Regulator of South Africa. Economic Review of Participation in Ports Operation and Services in South Africa. August, 2010. [Online] Available:

http://www.portsregulator.org/. (Accessed 15 February 2011).

Ports Regulator. (2010b). Record of Decision: Tariff Application by the National Ports Authority for the Tariff Year 2010/2011.

Ports Regulator. (2011). Record of Decision: Tariff Application by the National Ports Authority for the Tariff Year 2011/2012.

Ports Regulator. (2012). Record of Decision: Tariff Application by the National Ports Authority for the Tariff Year 2012/2013.

Ports Regulator. (2012b). Ports Regulator of South Africa. Global Port Comparator Study01/04/2012 Research Summary. Available at: http://www.portsregulator.org/ [Accessed 17 May 2013].

Ports Regulator. (2013). Ports Stakeholder Comments. [Online] Available: http://www.portsregulator.org/. (Accessed 26 November 2013).

Song, D.W. \& Lee, S.W. (2007). Port Governance in Korea, Devolution, Port Governance and Port Performance, Research in Transportation Economics, 17, pp. 357-375.

Stats SA. (2012). Consumer Price Index: September 2012. Statistical release P0141. [Online] Available: http://www.statssa.gov.za/publications/P0141/P0141September2012.pdf. (Accessed 25 October 2012).

Strandenes, S.P. \& Marlow, P.B. (2000). Port Pricing and Competitiveness in Short Sea Shipping. International Journal of Transport Economics, 27(3), October, pp. 315-334.

Thompson, L. (2009). Railway and Ports Organization in the Republic of South Africa and Turkey: The Integrator's Paradise? Proceedings of the International Transport Forum 2009. 0ECD. [Online] Available: http://www.internationaltransportforum.org/jtrc/discussionpapers/DP200905.pdf. (Accessed 15 April 2011).

TNPA. (2009). Tariff Application: 2010/11 tariff application to the Ports Regulator in terms of the National Ports Act, 2005 (Act No. 12 of 2005). Transnet National Ports Authority. 01 August.

TNPA. (2010). Tariff Application: 2011/12 Tariff application to the Ports Regulator in terms of the National Ports Act, 2005 (Act No. 12 of 2005). Transnet National Ports Authority. 31 July.

TNPA. (2011). Tariff Application: 2012/13 Tariff application to the Ports Regulator in terms of the National Ports Act, 2005 (Act No. 12 of 2005). Transnet National Ports Authority. 29 July.

TNPA. (2012a). Transnet National Ports Authority - Proposal for a New Tariff Structure. Available at: http://www.portsregulator.org/images/documents/TNPA_Pricing_Strategy September_12_2012.pdf (Accessed l April 2013).

Transnet. (2010). Transnet's Comments on the Ports Regulator's "Economic Review of Participation in Ports Operation and Services in South Africa", August 2010. [Online] Available:

http://www.portsregulator.org/Transnet_comments_on_Ports_Review.pdf. (Accessed 27 April 2011). 